This article was downloaded by: [Chalmers University of Technology]

On: 5 August 2008

Access details: Access Details: [subscription number 790388360]

Publisher Taylor \& Francis

Informa Ltd Registered in England and Wales Registered Number: 1072954 Registered office: Mortimer House, 37-41 Mortimer Street, London W1T 3JH, UK

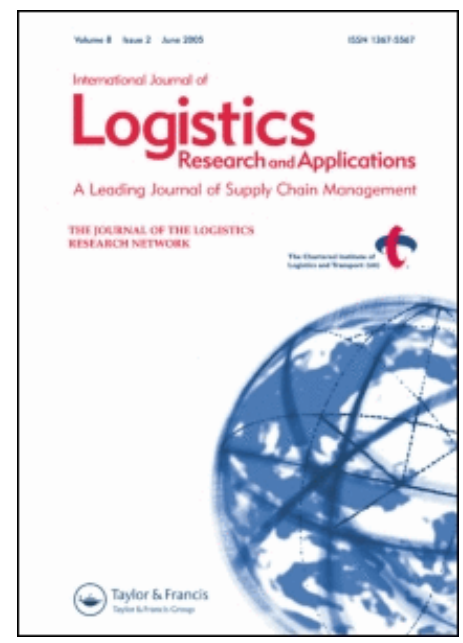

International Journal of Logistics Research and Applications

Publication details, including instructions for authors and subscription information:

http://www.informaworld.com/smpp/title content=t713435362

\title{
Perceived quality deficiencies of demand information and their consequences
}

Mattias Gustavsson a; Patrik Jonsson a

a Division of Logistics and Transportation, Chalmers University of Technology, Gothenburg, Sweden

First Published:August2008

To cite this Article Gustavsson, Mattias and Jonsson, Patrik(2008)'Perceived quality deficiencies of demand information and their consequences', International Journal of Logistics Research and Applications, 11:4,295 - 312

To link to this Article: DOI: $10.1080 / 13675560801952987$

URL: http://dx.doi.org/10.1080/13675560801952987

\section{PLEASE SCROLL DOWN FOR ARTICLE}

Full terms and conditions of use: http://www.informaworld.com/terms-and-conditions-of-access.pdf

This article may be used for research, teaching and private study purposes. Any substantial or systematic reproduction, re-distribution, re-selling, loan or sub-licensing, systematic supply or distribution in any form to anyone is expressly forbidden.

The publisher does not give any warranty express or implied or make any representation that the contents will be complete or accurate or up to date. The accuracy of any instructions, formulae and drug doses should be independently verified with primary sources. The publisher shall not be liable for any loss, actions, claims, proceedings, demand or costs or damages whatsoever or howsoever caused arising directly or indirectly in connection with or arising out of the use of this material. 


\title{
RESEARCH ARTICLE
}

\section{Perceived quality deficiencies of demand information and their consequences}

\author{
Mattias Gustavsson* and Patrik Jonsson \\ Division of Logistics and Transportation, Chalmers University of Technology, Gothenburg, Sweden
}

(Received 17 September 2007; final version received 30 January 2008)

\begin{abstract}
This paper focuses on the quality of demand information exchanged between customers and suppliers in supply chains. The first sub-purpose of the study is to describe the level and consequences of informationquality deficiencies of order and forecast information received by suppliers from their main customer. The second sub-purpose is to describe and compare the characteristics of companies and information with high and low information quality. The paper is based on a survey of Swedish manufacturing industry with 219 respondents. The results indicate that forecasts are considered deficient in terms of reliability, conciseness, timeliness and credibility while orders are considered deficient in terms of reliability. Further, companies with high levels of information-quality deficiencies were characterised by less active information management, and used less advanced planning software.
\end{abstract}

Keywords: survey; information quality; demand information; manufacturing planning and control

\section{Introduction}

The efficiencies of manufacturing planning and control (MPC) processes depend to some extent on the quality of the demand information (customer orders and forecasts) used. High-quality information can be characterised as being relevant, timely, reliable, and at the same time easy to access and understand (e.g. Lee et al. 2002, Petersen et al. 2005, Li and Lin 2006, Forslund and Jonsson 2007). Low-quality information may mean that the information is of little or no use at all.

The bullwhip effect is acknowledged as a major cause of supply chain inefficiency, and measures are taken in many industries to decrease order variability and increase supply chain performance. (Lee et al. 1997). Order variability can be explained by the information-quality variables of reliability and timeliness. Innovative strategies to handle order reliability (e.g. quick response) are being implemented to a large extent by industry leaders (Lee et al. 1997). However, it is time to acknowledge that information distortion has other possibilities of improvement, for example by improving information quality in a wider sense than only order reliability. Petersen et al. (2005)

\footnotetext{
*Corresponding author. Email: mattias.gustavsson@ chalmers.se

ISSN 1367-5567 print/ISSN 1469-848X online

(C) 2008 Taylor \& Francis

DOI: $10.1080 / 13675560801952987$

http://www.informaworld.com
} 
imply that information quality had a significant influence on decision-making effectiveness in supply chain planning activities. Fawcett et al. (1996) showed that the relationship between information capability, i.e. the company's ability to gather and disseminate useful information, and flexibility was positive. Li and Lin (2006) stated that organisations with low informationquality deficiencies are associated with high levels of top management support and IT enablers, and high levels of inter-organisational relationships. The level of information quality in companies increases IT impact on operations, which in turn has a positive impact on firm performance (Byrd and Davidson 2006). We may thus conclude that information quality should be a highly prioritised managerial issue (Swartz 2007) and that it is important to share high-quality information between customers and suppliers to support the MPC processes.

In MPC processes, several information types are used as input: e.g. business strategy, forecasts, customer orders, available resources, and inventory levels (Mattsson and Jonsson 2003). Most of these are created internally, others communicated between customers and suppliers, mainly represented by orders and forecasts (Forslund and Jonsson 2007). In this study, the focus lies on the information (order and forecast) received by the supplier from the main customer. Information quality is a complex phenomenon and can be characterised by several different variables. We lack knowledge of which variables are considered especially deficient and lead to the most severe consequences in companies. Hence, there is a need for further research that guides managers regarding which variables of information quality they should spend their improvement efforts on. Studies describing consequences of information-quality deficiencies, or best-practice studies are required.

This paper concerns the quality of forecast and order information, received from an external customer and used in an internal MPC process. In relation to this, we state two sub-purposes of the paper.

The first sub-purpose is to describe the levels and consequences of information-quality deficiencies in order and forecast information received by suppliers from their main customer.

It is not enough to know in what way different information-quality variables are considered deficient, and the consequences thereof, so as to manage information quality. To understand how to eliminate information-quality deficiencies and minimise their consequences, we also need to know the characteristics of the companies that consider the received order and forecast information to have high and low quality, respectively (e.g. Forslund and Jonsson 2007), as well as the information characteristics. The characteristics of companies in general - such as size, industry, and structure of the supply chain - create financial and knowledge bases for IT investments (Thong and Yap 1995) and information-quality improvement. Research in this area is ambiguous; information quality has been proved to increase IT success (Byrd and Davidson 2006), but company characteristics have not been related to IT success (Grover and Segars 1996).

The information characteristics can be divided into type - in this study, order or forecast and details describing how often the information is expressed and used internally at the receiver. Previous studies have not emphasised the impact of both type and details (Forslund and Jonsson 2007). The type and details of the information may influence the perceived information quality, but very few studies support this statement. Different types of companies have different prerequisites for successful information exchange, and thus different prerequisites for information-quality deficiency levels. The relations between company and information characteristics and information quality consequently need to be examined.

The second sub-purpose is to describe and compare the characteristics of companies and information with high and low information quality.

The paper is structured as follows. First, the research framework is developed on the basis of previous research. The next section explains the survey design and instrument. The findings are 
described in the Section 4, with reference to the two sub-purposes. The Section 5 discusses the findings and the sixth concludes the paper.

\section{Research framework}

According to the 2-fold purpose, information-quality deficiencies and consequences as well as the information and company characteristics need to be reviewed to develop a rigorous study design.

\subsection{Information quality}

There has been previous research in the area of perceived information-quality deficiency levels, mainly conducted through surveys. Daugherty et al. (1999) use a nine-dimensional informationquality construct in a study of automatic replenishment systems, ranking accessibility, format, timelines and accuracy as most deficient. Forslund and Jonsson (2007) study and rank accuracy, timeliness, accessibility, and reliability in forecasts. Lee et al. (2002) conducted a wider survey and identified the following ranking of deficient variables: reputation, conciseness, accessibility, and ease of operation. Closs et al. (1997) ranked the capability of information systems, where orders and forecasts rank equal - from format, through availability and timelines, to accuracy (Table 1). In general, accuracy and timeliness have high ranks in three of four rating systems. We can conclude that descriptive statistics on deficiency ranking differ between fields and information types, which further motivate a detailed description of deficiencies and consequence ranking in orders and forecasts for MPC process usage.

The consequences of information-quality deficiencies are mainly results of case studies focusing on one information-quality variable, or of surveys with highly aggregated information-quality indexes. Forslund (2004) provided an explanatory study from a planning decision perspective where the deficiencies in different variables explained different preventive and corrective MPC decisions. Forslund showed that timeliness and accuracy of the forecast and timeliness, reliability and accuracy of the order had significant correlations with several corrective planning decisions where the latter entailed high costs (Weheba and Elshennawy 2004).

Information quality can be divided into deficiency and consequences of the deficiency. Information quality is measurable in several ways: by using the variable in a straightforward question connected with a specific information type (Forslund and Jonsson 2007), by measuring costs related to the information-quality variable (English 1999) or by using several measures for every variable (Lee et al. 2002). In Table 2 the information-quality measures are presented, adapted to MPC usage by Gustavsson and Wänström (2008).

Table 1. Previous research on information-quality deficiencies.

\begin{tabular}{|c|c|c|}
\hline Author & $\begin{array}{l}\text { High deficiency variables } \\
\text { (top four in order) }\end{array}$ & Perspective \\
\hline $\begin{array}{l}\text { Daugherty } \\
\quad \text { et al. (1999) }\end{array}$ & $\begin{array}{l}\text { Accessibility, format, timeliness, } \\
\text { accuracy }\end{array}$ & $\begin{array}{l}\text { Customer, judgement of own order } \\
\text { capability }\end{array}$ \\
\hline $\begin{array}{l}\text { Forslund and } \\
\quad \text { Jonsson (2007) }\end{array}$ & $\begin{array}{l}\text { Accuracy, timeliness, } \\
\text { accessibility, reliability }\end{array}$ & $\begin{array}{l}\text { Suppliers judge the received forecast } \\
\text { information-quality deficiency }\end{array}$ \\
\hline Lee et al. (2002) & $\begin{array}{l}\text { Reputation, concise, accessible, } \\
\text { ease of operation }\end{array}$ & $\begin{array}{l}\text { Different industries, overall } \\
\text { information-quality level }\end{array}$ \\
\hline Closs et al. (1997) & $\begin{array}{l}\text { Format, accessibility, timeliness, } \\
\text { accuracy }\end{array}$ & $\begin{array}{l}\text { Rating of the own system } \\
\text { order/forecast capabilities }\end{array}$ \\
\hline
\end{tabular}

Note: Only comparable variables of information quality are chosen from previous research.

When the scale indicates positive capability, the rank was reversed to reflect low capability, i.e. risk of deficiency. 
Table 2. Information-quality variables (Gustavsson and Wänström 2008).

\begin{tabular}{|c|c|}
\hline Variable & Definition \\
\hline Complete & The extent to which the information is comprehensive for the planning tasks \\
\hline Concise & $\begin{array}{l}\text { The extent to which the information can be used directly, without a need of } \\
\text { reworking before use, in terms of format, content, and/or structure }\end{array}$ \\
\hline Reliable & $\begin{array}{l}\text { The extent to which the information provided to the planning staff is } \\
\text { accurate }\end{array}$ \\
\hline Timely & $\begin{array}{l}\text { The extent to which the information is delivered in time and at correct } \\
\text { intervals, i.e. not too often or too infrequently for the planning process }\end{array}$ \\
\hline Valid & The extent to which the information measures what it should measure \\
\hline Accessible & To which extent the planning information is easy to access when required \\
\hline Appropriate amount & The extent to which no filtration of the information is necessary \\
\hline Credible & $\begin{array}{l}\text { The extent to which planning information is accepted or regarded as true, } \\
\text { real, and believable }\end{array}$ \\
\hline Relevant & $\begin{array}{l}\text { The extent to which the planning information is appropriate for the tasks } \\
\text { and applications }\end{array}$ \\
\hline Understandable & $\begin{array}{l}\text { The extent to which information is easy to use but also easy to learn and } \\
\text { easy to manipulate, aggregate, and combine with other information }\end{array}$ \\
\hline
\end{tabular}

\subsection{Information characteristics}

Regarding information type, Closs et al. (1997) measured the capability in information systems handling order and forecasts, respectively. The results showed that the information-quality variables were ranked equally for orders and forecasts, but with significantly higher mean values for the accuracy, timeliness, availability, and format of the order information compared to the forecast information. This indicates higher capabilities in the information system dedicated to order management. From this study, we can conclude that orders may be managed more rigorously by more capable information systems.

Research on information characteristics and their influence upon information-quality deficiencies is, however, scarce. The frequency of order and forecast exchange between customers and suppliers should be correlated with high levels of inter-organisational integration (Kwon and Suh 2005), such as well-integrated information systems and/or agreed procedures for order management and forecasting, thereby creating prerequisites for mutually understanding the importance of low information-quality deficiencies. Also, the usage of information should influence the quality level. For example, an increasing number of people/processes dependent on the information should increase consequence levels. A higher level of aggregation in the planning task (e.g. long-term planning) should decrease consequence levels in certain information types, for example orders and short- to mid-term forecasts. Further, the level of aggregation can put some information-quality variables in focus and make others less important. For example, timely and concise information should be more important in operative processes. Research is scarce on how staff in different MPC processes perceive the quality of information and its consequences.

\subsection{Company characteristics}

The influence of different industries on information quality can be exemplified by just-intime strategies entailing extensive communication between customer and supplier (Scannell et al. 2000), correlated with high levels of involvement between the companies (Ward and Zhou 2006) and thereby with lower levels of information-quality deficiencies. Further, some industries, such as electronics and automobiles, work with more frequent and/or structured (EDI-standard) information exchange, which should create prerequisites for low information-quality deficiencies in terms of timeliness and reliability (Ahmad and Schroeder 2001). The level of integration, 
for example through information systems or collaborative planning activities, should generally improve information-quality levels but is of a dyadic character, so they are not included in this study where the companies' internal characteristics and information management are studied.

Internally, information systems need frequent updating and cleansing of data, as suggested by APICS (2007), which also facilitates lower levels of information-quality deficiencies, mainly in terms of reliability, validity, relevance, and appropriate amount. Data cleansing requires formal roles and responsibilities for information quality or information management, and is facilitated by the usage of Enterprise Resource Planning (ERP) systems (Spathis and Constantinides 2003). The usage of ERP systems is driven by a demand for real-time information exchange and internal as well as external integration (Spathis and Constantinides 2003). Hence, ERP systems and their extensions, such as advanced planning systems (APS) applications, should be beneficial in improving information quality. Further, with an implemented routine of information measurement $e . g$. forecast error), not only should the reliability be higher, but also the overall level of information-quality deficiencies should be lower.

\section{Survey design}

The two sub-purposes of this paper are both descriptive, aiming at understanding the relevance of the phenomenon, describing the distribution of the phenomenon in a population and providing a state-of-the-art description through a survey (Forza 2002). In this study, orders and forecasts received from the respondents' main customer are evaluated. The main customer is chosen as the one with the largest portion of the turnover. This selection is intended to avoid relationships with very low frequencies of information exchange since these can be dominated by low levels of integration. By studying well-developed relationships one can learn more about best practices in industry. The respondents are all production or logistics managers and the aim is to obtain answers about MPC activities and information exchange. The study contains three groups of variables: (1) information quality, (2) information characteristics, and (3) company characteristics (Figure 1) related to the two sub-purposes.

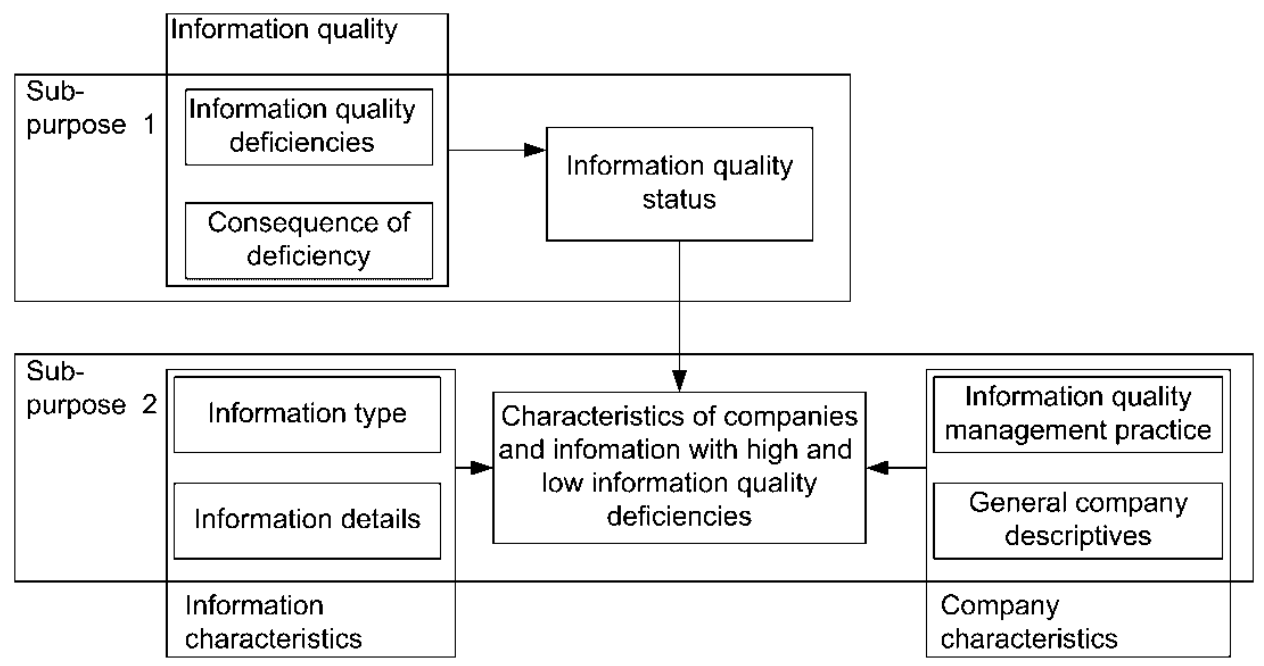

Figure 1. Study design. 


\subsection{Information quality}

For information quality, the variables from Gustavsson and Wänström (2008) are used with corresponding measures from Lee et al. (2002), but somewhat adapted to the context of demand information in an MPC process (Table 2). Measures adapted from Lee et al. (2002) are marked (a) while measures based directly on their definition (Gustavsson and Wänström 2008) are marked (b) in Table 3. The deficiency level multiplied by the consequence of the deficiency for the planning performance describes the information-quality criticality (Tables 4 and 5). Hence, a high deficiency level in combination with low consequences will give a medium criticality and vice versa. When operationalised, the variable of appropriate amount was included in the concise measures (Table 3); thereby nine variables were measured. This was a result of the slight overlap between these variables, which is hard to explain in a questionnaire without jeopardising the validity of the study.

\subsection{Information characteristics}

Information characteristics are divided into information type and details. Since the main customer of the respondent is in focus, we assume that only one type of order is received. If more than one type is received, the respondent is asked to complete the questionnaire with the one order type most crucial for MPC activities in mind. Regarding forecasts, we assume that several types can reach the respondent from one main customer - for example the delivery schedule, short-term product forecast, long-term product group forecast and/or capacity bookings - but the most influential type is identified in the questionnaire. Orders are characterised by the frequency of exchange and

Table 3. Information-quality constructs.

\begin{tabular}{|c|c|c|}
\hline Variables and questions & Forecast & Order \\
\hline \multicolumn{3}{|l|}{ Complete } \\
\hline The information includes all necessary values (a) & $\mathrm{C} 8$ & D1 \\
\hline The information includes all necessary explanations of the values (b) & C9 & D2 \\
\hline \multicolumn{3}{|l|}{ Concise } \\
\hline The information can be used directly, without reworking (b) & $\mathrm{C} 10$ & D3 \\
\hline \multicolumn{3}{|l|}{ Reliable } \\
\hline The information is correct, i.e. reflecting the true demand (a) & & D4 \\
\hline The forecast error is low and reflects true demand & $\mathrm{C} 11$ & \\
\hline \multicolumn{3}{|l|}{ Timely } \\
\hline The information is received in time for the planning task (b) & $\mathrm{C} 12$ & \\
\hline \multicolumn{3}{|l|}{ Valid } \\
\hline The customer uses the same measures as you are & $\mathrm{C} 13$ & \\
\hline The customer uses the same definitions as you are & & D5 \\
\hline \multicolumn{3}{|l|}{ Accessible } \\
\hline The information is easy to access at the customer when required (a) & $\mathrm{C} 14$ & \\
\hline The information is easily obtainable internally when it needs to be recreated (a) & $\mathrm{C} 15$ & \\
\hline \multicolumn{3}{|l|}{ Credible } \\
\hline The received information is believable (a) & $\mathrm{C} 16$ & D6 \\
\hline \multicolumn{3}{|l|}{ Relevant } \\
\hline The received information is relevant for the task/application (a) & $\mathrm{C} 17$ & \\
\hline \multicolumn{3}{|l|}{ Understandable } \\
\hline The information is easy to understand (b) & $\mathrm{C} 18$ & \\
\hline The information is easy to rework to fit our needs & $\mathrm{C} 19$ & \\
\hline
\end{tabular}

Note: For information-quality deficiencies a seven-point Likert scale, anchored by 'I do not agree for this information type' and 'I agree fully regarding this information type', is used. Corresponding consequences are measured with a seven-point Likert scales anchored by 'deficiencies in this dimension will not affect our production planning' and 'deficiencies in this dimension will severely affect our production planning'.

In constructs including two measures the mean of these is used, e.g. complete is measured as $(\mathrm{C} 8+\mathrm{C} 9) / 2$. 
typical quantity of orders as well as the matching between order quantity and production batches. Forecasts are characterised by the information's type, horizon, period, frequency. (Mattsson and Jonsson 2003), and importance in different MPC processes, as recommended by Forslund and Jonsson (2007), such as long-term planning of capacity and production, detailed control of materials and inventory, and detailed production planning (Wacker and Sheu 2006), but also by whether the information is used directly in communication with suppliers. The information characteristics' constructs are displayed in the Appendix (Table A1).

\subsection{Company characteristics}

Company characteristics can be divided into general company characteristics and information management practice. General company characteristics are described by questions A1-A7 (Table A2, Appendix) and derived for two reasons. To be able to make a relevant non-response bias analysis, the industry and size of the respondent are identified. Moreover, to describe the characteristics of companies with high and low perceived information-quality deficiencies, according to the second sub-purpose, the number of employees, turnover, customer importance, distance, and type as well as the respondents' supply chain position and product types are used.

Information management practices are described, and related to product quality management, by several researchers on the management of information systems (e.g. Fisher et al. 2006) and are here adapted to (1) managing the information as the product of a well-defined process, (2) managing the information as a product within a life cycle, (3) appointing an information product manager, (4) improving the planning process and making it more independent of informationquality deficiencies. Spathis and Constantinides (2003) proved that the usage of ERP and APS systems influences decision-making, and thus the extent to which these applications were used in the MPC process was measured.

\subsection{Scales}

Information quality and information characteristics variables were measured for the respondent's main customer. Some variables were measured on nominal scales, some on ordinal scales, and some on interval scales. Chi-square tests were used to compare variables with nominal scales. Mann-Whitney rank tests were used to compare variables on ordinal scale, $t$-tests and ANOVA for comparing means between variables on interval scales. Further, Spearman correlation tests were used on ordinal and interval data to test the stability in the significances from the aforementioned tests. The information-quality deficiency scales were reversed to reflect the same direction as consequences.

When dividing the respondents into groups of high and low information-quality deficiencies and consequences, some assumptions need to be clarified. First, we assume that being really satisfied with the information, i.e. low levels of information-quality deficiencies, should be reflected by only the two top levels of the seven-point Likert scale; reversed, this means that only alternatives one and two reflect low levels of information-quality deficiencies. From this, we create the low information-quality deficiencies group used in the analysis of the second sub-purpose (averages of 1-2.49). Likewise, we assume that high levels of information-quality deficiencies logically should be reflected by marking the seven-point Likert scale somewhere between the middle and seven; from this we create the high information-quality deficiencies group (3.5-7). In order to avoid random distribution of the samples in between groups, all respondents between 2.50 and 3.49 were excluded from the analysis. This gives two groups of fairly equal size, but also with enough respondents in each group to provide a basis for analysis. 


\subsection{Population}

The population of the study was companies in all types of industries with an own production facility, and with more than 50 employees. A total of 900 email addresses were selected from the Swedish address database (PAR); 60 of these did not have production and were thereby excluded. An email with a link to a web survey was distributed to all these addresses in March 2007, and 219 full responses were received, which corresponds to a response rate of $26 \%$. Two email reminders were sent out to the population and 276 companies were contacted for an extensive non-response bias analysis. The majority of the $276(63 \%)$ either asked for a new email and promised to answer, or gave a new contact person at the company to whom the web survey was sent. Five companies (2\%) claimed that they did not have the knowledge to answer the questions, another five worked at companies without a production facility and $92(33 \%)$ did not have the time. Hence, $96 \%$ of the non-response companies were relevant for the population and intended to answer or did not have the time available. The respondents represent companies of various sizes, more than half having less than 100 employees. A quarter of them are OEMs and almost $40 \%$ of them are more than $100 \mathrm{~km}$ from their main customer. For approximately a fifth of the respondents the main customer, which this study focuses on, accounts for more than $25 \%$ of the total turnover (Table A3, Appendix).

The non-response bias was analysed by comparing the industry affiliation and company sizes of the respondents and the entire selection (Table A4, Appendix). The division of industries is based on whether the production system is of more continuous process type or of more batch and mechanical engineering type. Chi-square tests revealed differences between respondents and the full selection in both industry and size. Process-industry type companies as well as mid-size companies were over-represented in the group of respondents. However, we consider that the findings should not be significantly affected by this bias. The PAR database includes addresses to all Swedish companies, so the selection can be considered representative for Swedish industry.

\section{Findings}

Findings of this study are presented in Section 4.1 for the first sub-purpose and in Section 4.2 for the second sub-purpose.

\subsection{Information-quality deficiencies and consequences}

The analyses related to the first purpose, to describe the levels and consequences of informationquality deficiencies in order and forecast information exchanged between suppliers and their main customer, are presented in Tables 4 and 5 where means and standard deviations of the information-quality variables are presented.

Table 4 compares the nine forecast information-quality variables on three dimensions: the perceived information-quality deficiency, the perceived consequence of information-quality deficiencies, and the information-quality factor. The factor was calculated (deficiency multiplied by consequence) in order to measure the criticality of the variables, considering both perceived deficiency and consequences. Forecast information-quality deficiencies show two groups of variables, concise, and reliable have the highest deficiencies and both significantly differ from five of the other seven information-quality variables. Further, valid and understandable have the lowest deficiencies and both differ significantly from four of the other seven information-quality variables. Only few differences in consequences were identified between the variables. However, reliability 
Table 4. Forecast information-quality factor.

\begin{tabular}{|c|c|c|c|c|c|c|}
\hline \multirow[b]{2}{*}{ Variable } & \multicolumn{2}{|c|}{$\begin{array}{l}\text { Information-quality } \\
\text { deficiency }\end{array}$} & \multicolumn{2}{|c|}{$\begin{array}{l}\text { Information-quality } \\
\text { consequence }\end{array}$} & \multicolumn{2}{|r|}{$\begin{array}{l}\text { Information-quality } \\
\text { factor }\end{array}$} \\
\hline & Rank & Mean (SD) & Rank & Mean (SD) & Rank & Mean (SD) \\
\hline $\begin{array}{l}\text { 1. Complete } \\
\text { information }\end{array}$ & 7 & 2.89 (1.84) $[2,3,4]$ & 5 & $4.35(1.66)[-]$ & 7 & $11.53(7.90)[2,3,4,7]$ \\
\hline $\begin{array}{l}\text { 2. Concise } \\
\text { information }\end{array}$ & 1 & $3.97(2.21)[1,5,6,8,9]$ & 8 & $3.98(1.70)[3,4,7]$ & 4 & $16.21(11.36)[1,3,5,6,9]$ \\
\hline $\begin{array}{l}\text { 3. Reliable } \\
\text { information }\end{array}$ & 2 & 3.95 (1.65) $[1,5,6,8,9]$ & 1 & $4.92(1.44)[2,6,9]$ & 1 & $19.74(10.02)[1,2,5,6,8,9]$ \\
\hline $\begin{array}{l}\text { 4. Timely } \\
\text { information }\end{array}$ & 3 & $3.69(1.99)[1,5,6,9]$ & 3 & 4.73 (1.59) [2] & 2 & $17.42(10.87)[1,5,6,8,9]$ \\
\hline $\begin{array}{l}\text { 5. Valid } \\
\text { information }\end{array}$ & 9 & 2.45 (1.66) $[2,3,4,7]$ & 5 & $4.35(1.82)[-]$ & $\begin{array}{l}8 \\
8\end{array}$ & $10.51(8.39)[2,3,4,7]$ \\
\hline $\begin{array}{l}\text { 6. Accessible } \\
\text { information }\end{array}$ & 6 & $2.94(1.42)[2,3,4]$ & 6 & $4.27(1.55)[4]$ & 6 & $12.29(7.25)[2,3,4,7]$ \\
\hline $\begin{array}{l}\text { 7. Credible } \\
\text { information }\end{array}$ & 4 & $3.47(1.63)[5,9]$ & 2 & 4.85 (1.38) [2,9] & 3 & $16.79(9.07)[1,5,6,9]$ \\
\hline $\begin{array}{l}\text { 8. Relevant } \\
\text { information }\end{array}$ & 5 & $3.07(1.65)[2,3]$ & 4 & $4.58(1.54)[-]$ & 5 & $13.69(8.55)[3,4]$ \\
\hline $\begin{array}{l}\text { 9. Understandable } \\
\text { information }\end{array}$ & 8 & $2.48(1.31)[2,3,4,7]$ & 7 & $4.22(1.60)[3,7]$ & 9 & $10.49(6.92)[2,3,4,7]$ \\
\hline
\end{tabular}

Note: Information-quality factor equals information-quality deficiency multiplied by information-quality consequence.

Numbers in brackets [ ] indicate variable number with the variable significantly different $(p<0.05)$ using Bonferroni post hoc tests.

1 - indicates low levels of information-quality deficiencies and 7-indicates high levels of information-quality deficiencies.

had the highest consequence and concise the lowest. The most critical variable, reliability, differs significantly from all the others except timeliness and credibility. The same four variables with the highest perceived deficiencies were also top ranked in terms of criticality. One finding, though, is that the criticality of the top four deficient variables differed in rank because of their high perceived consequences. Reliable was considered most critical, followed by timely, credible, and concise.

Table 5. Customer order information-quality factor.

\begin{tabular}{|c|c|c|c|c|c|c|}
\hline \multirow[b]{2}{*}{ Variable } & \multicolumn{2}{|c|}{$\begin{array}{l}\text { Information-quality } \\
\text { deficiency }\end{array}$} & \multicolumn{2}{|c|}{$\begin{array}{l}\text { Information-quality } \\
\text { consequence }\end{array}$} & \multicolumn{2}{|c|}{$\begin{array}{l}\text { Information-quality } \\
\text { factor }\end{array}$} \\
\hline & Rank & Mean (SD) & Rank & Mean (SD) & Rank & Mean (SD) \\
\hline $\begin{array}{l}\text { 1. Complete } \\
\text { information }\end{array}$ & 5 & $2.08(1.26)[2,3]$ & 2 & $4.71(1.86)[-]$ & 5 & $9.47(6.46)[2,3]$ \\
\hline $\begin{array}{l}\text { 2. Concise } \\
\text { information }\end{array}$ & 2 & $2.93(1.88)[1,4,5]$ & 5 & $4.33(1.86)[5]$ & 2 & $12.20(9.62)[1,3]$ \\
\hline $\begin{array}{l}\text { 3. Reliable } \\
\text { information }\end{array}$ & 1 & $3.17(1.70)[1,4,5]$ & 3 & $4.70(1.54)[-]$ & 1 & $15.22(10.10)[1,2,4,5]$ \\
\hline $\begin{array}{l}\text { 4. Valid } \\
\text { information }\end{array}$ & 4 & $2.28(1.52)[2,3]$ & 4 & $4.54(1.83)[-]$ & 4 & $9.78(6.85)[3]$ \\
\hline $\begin{array}{l}\text { 5. Credible } \\
\text { information }\end{array}$ & 3 & $2.45(1.49)[2,3]$ & 1 & 4.88 (1.69) [2] & 3 & $11.78(8.23)[3]$ \\
\hline
\end{tabular}

Note: Information-quality factor equals information-quality deficiency multiplied by information-quality consequence.

Numbers in brackets [ ] indicate variable number with the variable significantly different $(p<0.05)$ using Bonferroni post hoc tests.

1 - indicates low levels of information-quality deficiencies and 7-indicates high levels of information-quality deficiencies. 
Order information-quality deficiencies also show two groups of variables. Reliable and concise are the most deficient variables and significantly differ from the other three. Only small differences existed between variables regarding consequences, and thus the factor variables followed the same pattern as the deficiency variables. For the information-quality factor, reliability is the most critical variable, significantly differing from the other four variables (Table 5).

\subsection{High and low information-quality deficiencies}

To analyse the second purpose, to describe and compare the characteristics of companies and information with high and low information quality, the respondents were grouped into sub-groups based on their perceived information-quality deficiencies, resulting in a low forecast information-quality deficiency group of 44 respondents and a high forecast information-quality deficiency group of 68 respondents (Tables 6 and 7). For the order information-quality deficiency the corresponding groups contained 106 and 51 respondents, respectively (Tables 8 and 9).

The significantly different forecast information characteristics between those with low and high forecast information-quality deficiencies, respectively, were that those with low forecast information-quality deficiencies had a shorter forecast period and lower forecast frequency. The group of companies with low level of information-quality deficiencies also used the forecast as a delivery plan to a significantly greater extent than the other group, which used the forecast on a more aggregated level. Further, low forecast information-quality deficiency information was characterised by information with a high importance for long-term planning, materials planning and production activity control. Spearman correlation tests between forecast information quality and information characteristics also revealed a significant correlation between using the forecast in upstream communication, and low information-quality deficiencies (see Table 6).

Comparing the use of order information characteristics showed that those perceiving the information-quality deficiencies to be low had a significantly higher frequency of order exchange

Table 6. Forecast information quality and information characteristics.

\begin{tabular}{|c|c|c|c|}
\hline Variable & $\begin{array}{c}\text { Low } \\
\text { information-quality } \\
\text { deficiencies } \\
(n=44)\end{array}$ & $\begin{array}{l}\text { High } \\
\text { information-quality } \\
\text { deficiencies } \\
(n=68)\end{array}$ & Statistics \\
\hline C2a Forecast as delivery plan [no. (\%)] & $27(61 \%)$ & $21(31 \%)$ & $\begin{array}{c}\text { Chi-square: } \\
10.14 * *\end{array}$ \\
\hline C2b Forecast horizon [mean rank] & 62 & 52 & MW: 1.81 \\
\hline C2c Forecasting period [mean rank] & 44 & 64 & MW: $3.39 * *$ \\
\hline C2d Forecasting frequency [mean rank] & 42 & 65 & MW: $4.10^{* *}$ \\
\hline C3a Forecast accuracy measurement [no. (\%)] & $22(50 \%)$ & $23(34 \%)$ & $\begin{array}{c}\text { Chi-square: } \\
2.91\end{array}$ \\
\hline $\begin{array}{l}\text { C4 Important input to long-term planning } \\
\text { [mean (SD)] }\end{array}$ & $6.32(1.18)$ & $5.41(1.37)$ & $t: 3.60 * *$ \\
\hline $\begin{array}{l}\text { C5 Important input to materials planning } \\
\text { [mean (SD)] }\end{array}$ & $5.82(1.48)$ & $4.90(1.76)$ & $t: 2.88^{* *}$ \\
\hline $\begin{array}{l}\text { C6 Important input to production activity } \\
\text { control [mean (SD.)] }\end{array}$ & $5.36(1.91)$ & $4.25(1.95)$ & $t: 2.96^{* *}$ \\
\hline $\begin{array}{l}\text { C7 Important communication to suppliers } \\
\text { [mean (SD)] }\end{array}$ & $5.66(1.68)$ & $5.16(1.69)$ & $t: 1.52$ \\
\hline
\end{tabular}

Note: $t$-tests, Chi-square and Mann-Whitney (MW) mean rank tests to compare groups.

*Significant on $p<0.05$ level, **significant on $p<0.01$ level.

Spearman's correlation tests between forecast information quality and information characteristics showed the same significances for the whole population except for variable C7 which was significantly correlated $(p<0.01)$. 
Table 7. Forecast information quality and company characteristics.

\begin{tabular}{|c|c|c|c|}
\hline Variable & $\begin{array}{c}\text { Low } \\
\text { information-quality } \\
\text { deficiencies } \\
(n=44)\end{array}$ & $\begin{array}{c}\text { High } \\
\text { information-quality } \\
\text { deficiencies } \\
(n=68)\end{array}$ & Statistics \\
\hline E1 Managing info process [mean (SD)] & $4.51(1.55)$ & $3.97(1.32)$ & $t: 1.91$ \\
\hline E2 Managing info life cycle [mean (SD.)] & $5.31(1.42)$ & $4.26(1.38)$ & $t: 3.77 * *$ \\
\hline E4 ERP/APS support [mean (SD)] & $4.83(1.63)$ & $3.78(1.66)$ & $t: 3.16^{* *}$ \\
\hline E3a information-quality responsibility [no. (\%)] & $35(85 \%)$ & $37(58 \%)$ & $\begin{array}{c}\text { Chi-square: } \\
8.80^{* * *}\end{array}$ \\
\hline E3b Information management responsibility [no. (\%)] & $34(83 \%)$ & $39(61 \%)$ & $\begin{array}{c}\text { Chi-square: } \\
5.70^{*}\end{array}$ \\
\hline A1 No. of employees [mean rank] & 59 & 55 & MW: 0.60 \\
\hline A 2 Company turnover [mean rank] & 58 & 55 & MW: 0.52 \\
\hline A3 Customer importance [mean rank] & 67 & 50 & MW: $2.76^{* *}$ \\
\hline A4 Customer distance [mean rank] & 54 & 58 & MW: 0.80 \\
\hline A5b Manufacturer as customer [no. (\%)] & $27(61 \%)$ & $39(57 \%)$ & $\begin{array}{c}\text { Chi-square: } \\
0.18\end{array}$ \\
\hline A6a OEM company [no. (\%)] & $17(39 \%)$ & $35(52 \%)$ & $\begin{array}{c}\text { Chi-square: } \\
1.77\end{array}$ \\
\hline A7a Customer-specific items [no. (\%)] & $29(66 \%)$ & $34(51 \%)$ & $\begin{array}{c}\text { Chi-square: } \\
2.49\end{array}$ \\
\hline
\end{tabular}

Note: $t$-tests, Chi-square and Mann-Whitney (MW) mean rank tests to compare groups. *Significant on $p<0.05$ level, **significant on $p<0.01$ level.

Spearman's correlation tests between forecast information quality and company characteristics showed the same significances for the whole population except for variable E1 which was significantly correlated $(p<0.01)$.

Table 8. Customer order information quality and information characteristics.

\begin{tabular}{|c|c|c|c|}
\hline Variable & $\begin{array}{c}\text { Low } \\
\text { information-quality } \\
\text { deficiencies } \\
(n=106)\end{array}$ & $\begin{array}{c}\text { High } \\
\text { information-quality } \\
\text { deficiencies } \\
(n=51)\end{array}$ & Statistics \\
\hline B3 Order frequency [mean rank] & 86 & 63 & MW: $3.22 * *$ \\
\hline B6 Batch size in manufacturing [mean rank] & 78 & 80 & MW: 0.26 \\
\hline
\end{tabular}

Note: Mann-Whitney (MW) mean rank tests to compare groups.

*Significant on $p<0.05$ level, **significant on $p<0.01$ level. Spearman's correlation tests between customer order information quality and information characteristics showed the same significances for the whole population.

(Table 7) while the batch size did not differ at all. It is hard to interpret the results regarding batch sizes, since these should be correlated with the order frequency.

The respondents with perceived low and high forecast information-quality deficiencies differed significantly regarding some company characteristics and in how they handled the information processes (Table 8). Those with low perceived forecast information-quality deficiency represented companies with significantly more developed information life cycle management and ERP or APS system support. Spearman tests showed that the information-process management also had a positive impact on forecast information quality. Further, companies with low levels of information-quality deficiency mainly had a more important customer in terms of portion of the turnover. The low information-quality deficiency group also, to a significantly greater extent, employed an information-quality supervisor or an information management director. The large number of companies (35) with an official staff responsibility for information quality was somewhat surprising, but might indicate that the two questions (E3a and E3b) are too close to each other. 
Table 9. Customer order information quality and company characteristics.

\begin{tabular}{|c|c|c|c|}
\hline Variable & $\begin{array}{c}\text { Low } \\
\text { information-quality } \\
\text { deficiencies } \\
(n=106)\end{array}$ & $\begin{array}{c}\text { High } \\
\text { information-quality } \\
\text { deficiencies } \\
(n=51)\end{array}$ & Statistics \\
\hline E1 Managing info process [mean (SD)] & $4.39(1.26)$ & $3.85(1.40)$ & $t: 2.37^{*}$ \\
\hline E2 Managing info life cycle [mean (SD)] & $4.99(1.44)$ & $4.14(1.19)$ & $t: 3.55^{* *}$ \\
\hline E4 ERP/APS support [mean (SD)] & $4.33(1.71)$ & $3.96(1.65)$ & $t: 1.26$ \\
\hline E3a information-quality responsibility [no. (\%)] & $85(82 \%)$ & $32(64 \%)$ & $\begin{array}{c}\text { Chi-square } \\
5.82 *\end{array}$ \\
\hline E3b Information-management responsibility [no. (\%)] & $89(85 \%)$ & $31(62 \%)$ & $\begin{array}{c}\text { Chi-square } \\
10.04 * *\end{array}$ \\
\hline A1 No. of employees [mean rank] & 78 & 81 & MW: 0.42 \\
\hline A2 Company turnover [mean rank] & 79 & 79 & MW: 0.10 \\
\hline A3 Customer importance [mean rank] & 84 & 68 & MW: $2.14 *$ \\
\hline A4 Customer distance [mean rank] & 78 & 81 & MW: 0.42 \\
\hline A5b Manufacturer as customer [no. (\%)] & $48(46 \%)$ & $29(57 \%)$ & $\begin{array}{c}\text { Chi-square: } \\
1.57\end{array}$ \\
\hline A6a OEM company [no. (\%)] & $54(51 \%)$ & $25(49 \%)$ & $\begin{array}{c}\text { Chi-square: } \\
0.05\end{array}$ \\
\hline A7a Customer-specific items [no. (\%)] & $54(51 \%)$ & $24(47 \%)$ & $\begin{array}{c}\text { Chi-square: } \\
0.262\end{array}$ \\
\hline
\end{tabular}

Note: $t$-tests, Chi-square and Mann-Whitney (MW) mean rank tests to compare groups. *Significant on $p<0.05$ level, **significant on $p<0.01$ level.

Spearman's correlation tests between customer order information quality and company characteristics showed the same significances for the whole population, except for E1 which did not show any significant correlation and E4 which showed significant correlation $(p<0.05)$

For order information quality, companies with low levels of information-quality deficiency were to a significantly greater extent working with information life cycle management, and had an information management and information-quality official assigned. Spearman tests showed no significance of how well developed the information management process was in the whole population; hence this finding in $t$-tests in Table 9 could be questioned, however the correlation between ERP or APS system support and order information quality was significant.

\section{Discussion}

The discussion follows the two sub-purposes, starting with the level and consequence of information-quality deficiencies, and proceeding to the information and company characteristics in relation to information-quality deficiencies.

\subsection{Information-quality deficiencies}

Previous research on information-quality deficiencies is both confirmed and supplemented by this study. Table 10 describes the ranking based on mean values of the top four variables, compared to previous research. The ranking of order information-quality deficiency variables showed significant differences between the top two and the remaining three variables (Table 5). Forecast information-quality deficiencies show that concise and reliable have the highest deficiencies and both significantly differ from five of the other seven information-quality variables (Table 4). The applied information-quality variables differ from previous research in the division of accuracy in reliability and validity, where both occur as top four variables. Order and 
Table 10. Information characteristics.

\begin{tabular}{|c|c|c|c|c|c|c|}
\hline \multirow[b]{2}{*}{ No. } & \multicolumn{3}{|c|}{ Forecast information-quality deficiencies } & \multicolumn{3}{|c|}{ Order information-quality deficiencies } \\
\hline & This study & $\begin{array}{l}\text { Forslund and } \\
\text { Jonsson (2007) }\end{array}$ & $\begin{array}{l}\text { Closs et al. } \\
\text { (1997) }\end{array}$ & This study & $\begin{array}{c}\text { Daugherty et al. } \\
\text { (1999) }\end{array}$ & $\begin{array}{l}\text { Closs et al. } \\
\text { (1997) }\end{array}$ \\
\hline 1 & Concise & Accuracy & Format & Reliable & Accessibility & Format \\
\hline 2 & Reliable & Timeliness & Accessibility & Concise & Format & Accessibility \\
\hline 3 & Timely & Accessibility & Timeliness & Credible & Timeliness & Timeliness \\
\hline 4 & Credible & Reliability & Accuracy & Valid & Accuracy & Accuracy \\
\hline
\end{tabular}

forecast credibility appear only in this study (Table 10); this can be explained by the respondents' proximity to the order fulfilment process as a part of the MPC process. Credibility is, however, the top deficiency variable in the more general survey by Lee et al. (2002), and is often explained as a result of longitudinal deficiencies in other variables, such as reliability (e.g. Fisher et al. 2006).

We can also note that three out of four of the most deficient variables in this study (concise, reliable, timely) reflect deficiencies in relation to planning rules or restrictions, and one (credibility) reflects the difference between users' expected and perceived value of the information. It is natural to conclude that credibility can be a result of deficiencies in the other three variables.

Concise information is defined as 'information that can be used directly without reworking', and is ranked as the most and second most deficient variable in forecasts and orders respectively. The consequences of conciseness were very low in both orders and forecasts, implying that reworking of information is not very resource-demanding since it is often about converting text to spreadsheets or vice versa. Further, by doing this, a control mechanism for information quality is implicitly included. For forecasts, the consequences differed from the deficiencies in ranking reliable, credible, timely, and relevant as the top four. Since the forecast is a prediction of the future, used for MPC processes, it is not surprising that reliability and credibility are top-ranked consequences. The high consequence of timeliness tells us that the forecasts are used in the formal MPC processes, and accentuates the importance of the forecast information quality.

Credibility is the information-quality variable with highest perceived consequences for orders and second highest for forecasts. Credibility is thus a key variable in information-quality management. It can be considered as reflecting deficiencies in other variables and should thereby be taken seriously and back-tracked before improvement actions are taken.

\subsection{Information characteristics}

The findings show that information-quality deficiencies are lower in orders than forecasts but the consequences are equal and high in both. This supports the study by Closs et al. (1997) implying that information systems are more capable of sustaining low information-quality deficiency for orders than forecasts.

The notions that a high frequency of exchange should, through high integration levels (Kwon and Suh 2005) and IT development, provide low levels of information-quality deficiencies proved to be significant for orders, but for the forecasts it turned out to have a significantly negative impact on the quality deficiencies. This can be explained by information systems not being capable of handling high-frequency forecast exchange (Closs et al. 1997), or by information overload for the user of the forecasts. Companies experiencing low forecast information-quality deficiencies considered the forecast to be a more important input into their long-term and materials planning 
processes as well as in production activity control. Obviously, those who need good forecasts also have good forecasts to a greater extent than those who do not need them. This can be interpreted in two ways: those who rely on proper forecasts also take necessary actions in order to receive good forecasts, or companies that have access to good forecasts also have designed planning processes that are dependent on good forecasts.

We can conclude that managerial efforts should be focussed on forecast information system development and on how forecasts are exchanged between companies in the supply chain, in order to establish a solid basis for high-quality forecast exchange.

The external use of the forecast information (i.e. information communicated to suppliers) showed influence on the perceived information-quality level. Hence, companies working with information sharing in the supply chain can be considered to have a higher consciousness regarding information quality and how it should be managed. This also implies that upstream supply chain integration is developed. The shorter the forecasting period, the lower the levels of informationquality deficiencies. This is logically explained by the intended usage of the forecast: the longer the horizons, the lower the need for high information quality, while short horizon forecasts normally are used at operative levels. This can be exemplified by the significantly higher percentage of companies in the low information-quality deficiency group working with the forecast as a delivery plan.

\subsection{Company characteristics}

Forecast information-quality deficiencies were significantly lower in companies with welldeveloped information life cycle management, information-process management, and highly utilised information systems. The learning outcomes are that if resources are limited, improvement should be focussed on these activities, with information life cycle management such as cleansing information systems from old data and duplicates and frequently updating ERP data, or information-process management such as regular reviews of information requirements and utilising information mapping to understand the complex information flows of the order fulfilment and MPC system. Further, companies with well developed and highly utilised information systems seem to have better knowledge of information-quality requirements and consequences, mainly due to the implementation processes rather than the system itself. Companies with an assigned information quality and information management official proved to have lower levels of information-quality deficiencies, implying that this type of managerial focus provides results.

In orders, the companies with well-developed information management practices showed low order information-quality deficiencies. However, the use of information systems showed no significance in improving order information quality. The findings of Closs et al. (1997) indicating that information systems are mainly dedicated to order management can be supported by the lower levels of order information-quality deficiencies and that the information system usage seems to have reached maturity. Assignment of information quality and information management officials showed significance in the expected direction by being higher in the low deficiency group.

The customers' relative importance to the respondent proved to be important for achieving high order and forecast information quality. The larger the customer, the lower are the levels of information-quality deficiencies. This can be interpreted to mean that the more influential the customer, the more probable it is that the supplier benefits by improving the information exchange. The distance between the customer and the supplier showed no significant impact on either forecast or order information-quality levels. If the question were to include longer distances, the results might differ. 


\section{Conclusions}

In this paper, two sub-purposes have been dealt with, the first being to describe the levels and consequences of information-quality deficiencies in order and forecast information received by suppliers from their main customer. Overall, information-quality deficiencies are lower in orders than in forecasts; the consequences are considered equal but high in both. We can conclude that the variables concise, reliable, timely, and credible showed the highest levels of deficiency, in forecasts. For orders, the variables were reliable, concise, credible, and valid. Orders had the highest perceived consequences in the variables credible, complete, reliable, and valid while forecasts showed the highest perceived consequences in the variables reliable, credible, timely, and relevant.

The second sub-purpose was to describe and compare the characteristics of companies and information with high and low information-quality. Companies with low information-quality deficiencies are working actively with information life cycle and process management. Information life cycle management is described as cleansing information systems from old data and duplicates and frequently updating ERP data. Information-process management is described by information flow mapping, information requirement mapping, both internally and externally, and actively confronting the source of the problem. Further, information systems (ERP and APS) usage is more developed in companies with low levels of forecast information-quality deficiencies. In general, information management practices seem to be better developed the larger the customer is, implying lower levels of information-quality deficiencies.

To summarise the managerial implications of this study, we can conclude that reliability and credibility are the information-quality variables with highest perceived consequences and reliability and conciseness are the ones considered most deficient. However, deficiencies in the dimension conciseness showed very low consequence levels. These variables are thus important to consider in improvement actions. Information life cycle and process management with a clear information-quality responsibility is important for high-quality information. According to the study, the potential and importance of information system improvements are greatest for forecast information exchange.

This study has limitations and further research is needed to improve the understanding of this area. First, only internal characteristics are considered; hence, for example, the level of integration between companies and collaborative planning initiatives should improve information quality and needs to be studied further. The impact of different strategies for decreasing informationquality deficiencies and consequences needs to be evaluated further through explanatory studies. Knowledge is lacking on how to design the information exchange in terms of relationships and information and communication technologies, and how to design and execute information life cycle and process management for low information-quality deficiencies.

In this study, the consequences of information-quality deficiency have been expressed and discussed in a very general way; their actual impacts on operations (in terms of how, and to what extent) have not been investigated and this is clearly and area justifying further research.

In addition, the correlation between credibility and the other information-quality variables needs to be examined further to provide guidelines on back-tracking and managing informationquality deficiencies. Moreover, the impact of distance to suppliers on information-quality levels could be further evaluated by using longer distances in the questionnaire. Logically, the relationship should be strong and information-quality levels should be better in a geographically close relationship than in a long-distance relationship. Finally, information-quality deficiencies can to a large extent be explained by the same causes as the well-known bullwhip effect and the actions taken to counter the effects are essentially similar. The main improvement areas related to the bullwhip effect are identified. (Lee et al. 1997) as using point-of-sales data to ensure high 
timeliness and reliability, using electronic data interchange, ensuring accessibility and reliability, sharing sales, capacity and inventory data, ensuring accessibility, and using a discount system for supply chain information sharing. The relationships between these improvement areas and the suggested information-quality variables as well as others are interesting topics for continued research.

\section{References}

Ahmad, S. and Schroeder, R.G., 2001. The impact of electronic data interchange on delivery performance. Production and Operations Management, 10 (1), 16-30.

APICS, 2007. APICS certified supply chain professional - using information technology to enable supply chain management. Alexandria: APICS.

Byrd, T.A. and Davidson, N.W., 2006. An empirical examination of a process-oriented IT business success model. Information Technology and Management, 7, 55-69.

Closs, D.J., Goldsby, T.J. and Clinton, S.R., 1997. Information technology influences on world class logistics capability. International Journal of Physical Distribution and Logistics Management, 27 (1), 4-17.

Daugherty, P.J., Myers, M.B. and Autry, C.W., 1999. Automatic replenishment programs: an empirical examination. Journal of Business Logistics, 20 (2), 63-82.

English, L.P., 1999. Improving data warehouse and business information quality. New York: John Wiley \& Sons, Inc.

Fawcett, S.E., Calantone, R.J. and Smith, S.R., 1996. An investigation of the impact of flexibility on global reach and firm performance. Journal of Business Logistics, 17 (2), 167-196.

Fisher, C., Lauria, E., Chengalur-Smith, S. and Wang, R., 2006. Introduction to information quality. Boston: M.I.T. Information Quality Program Publications.

Forslund, H., 2004. The existence of logistics quality deficiencies and the impact of information quality in the dyadic order fulfilment process. Linköping University.

Forslund, H. and Jonsson, P., 2007. The impact of forecast information quality on supply chain performance. International Journal of Operations and Production Management, 27 (1), 90-107.

Forza, C., 2002. Survey research in operations management: a process-based perspective. International Journal of Operations and Production Management, 22 (2), 152-194.

Grover, V. and Segars, H., 1996. The relationship between organizational characteristics and information system structure: an international survey. International Journal of Information Management, 16 (1), 9-25.

Gustavsson, M. and Wänström, C., 2008. Assessing information quality in manufacturing planning and control processes, internal publishing series. Division of Logistics and Transportation, Chalmers University of Technology.

Kwon, I.-W. and Suh, T., 2005. Trust, commitment and relationships in supply chain management: a path analysis. Supply Chain Management: an International Journal, 10 (1), 26-33.

Lee, H.L., Padmanabhan, V. and Whang, S., 1997. The bullwhip effect in supply chains. Sloan Management Review, 38 (3), 93-103.

Lee, Y.W., Strong, D.M., Kahn, B.K. and Wang, R.Y., 2002. AIMQ: a methodology for information quality assessment. Information and Management, 40 (2), 133-146.

Li, S. and Lin, B., 2006. Accessing information sharing and information quality in supply chain management. Decision Support Systems, 42 (3), 1641-1656.

Mattsson, S.-A. and Jonsson, P., 2003. Produktionslogistik. Lund: Studentlitteratur.

Petersen, K.J., Ragatz, G.L. and Monczka, R.M., 2005. An examination of collaborative planning effectiveness and supply chain performance. The Journal of Supply Chain Management: a Global Review of Purchasing and Supply, 41 (2), $14-25$.

Scannell, T.V., Vickery, S.K. and Dröge, C.L., 2000. Upstream supply chain management and competitive performance in the automotive supply chain. Journal of Business Logistics, 21 (1), 23-48.

Spathis, C. and Constantinides, S., 2003. The usefulness of ERP systems for effective management. Industrial Management and Data Systems, 103 (9), 677-685.

Swartz, N., 2007. Gartner warns firms of 'dirty data'. Information Management Journal, 41 (3), 6.

Thong, J. and Yap, C., 1995. CEO characteristics, organizational characteristics and information technology adoption in small business. Omega International Journal of Management Science, 23 (4), 429-442.

Wacker, J.G. and Sheu, C., 2006. Effectiveness of manufacturing planning and control systems on manufacturing competitiveness: evidence from global manufacturing data. International Journal of Production Research, 44 (5), $1015-1036$.

Ward, P. and Zhou, H., 2006. Impact of information technology integration and lean/just-in-time practices on lead-time performance. Decision Sciences, 37 (2), 177-2036.

Weheba, G.S. and Elshennawy, A.K., 2004. A revised model for the cost of quality. International Journal of Quality and Reliability Management, 21 (3), 291-308. 


\section{Appendix}

Table A1. Information characteristics.

\begin{tabular}{|c|c|}
\hline Variables & Questions \\
\hline \multicolumn{2}{|l|}{ Information type } \\
\hline Forecast or order & $\begin{array}{l}\text { Order mandatory. } \\
\mathrm{C} 1 \text { - Forecast received from main customer? Yes/No }\end{array}$ \\
\hline \multicolumn{2}{|l|}{ Information details } \\
\hline $\begin{array}{l}\text { What characterises typical } \\
\text { orders (B3) }\end{array}$ & $\begin{array}{l}\text { Single choice: few large a year, several large a year, large amounts of orders } \\
\text { and moderate quantities, highly frequent call-offs against delivery schedules }\end{array}$ \\
\hline $\begin{array}{l}\text { How large are the typical production } \\
\text { batch sizes? (B6) }\end{array}$ & $\begin{array}{l}\text { Single choice: Equal to order quantities, small (approximately } 1 \text { week of } \\
\text { demand), medium (approximately a couple of weeks of demand), large } \\
\text { (approximately } 1 \text { month or more of demand) }\end{array}$ \\
\hline Forecast details (C2) & $\begin{array}{l}\text { Single choice questions. a) forecast type: delivery schedule, forecast of } \\
\text { products, forecast on product group, capacity forecast, oral, other. b) horizon: } \\
1-3,4-6,7-12 \text {, more than } 12 \text { months. c) period: day, week, month, quarter, } \\
\text { year. d) frequency: weekly, monthly, quarterly, yearly }\end{array}$ \\
\hline Forecast error measurement (C3) & Yes/No \\
\hline Intended usage $(\mathrm{C} 4-\mathrm{C} 7)$ & $\begin{array}{l}\text { Seven-point Likert scale (not at all important - very important): How important } \\
\text { is this information type for your long-term capacity and production planning, } \\
\text { material and inventory control, detailed production planning, communication } \\
\text { with suppliers }\end{array}$ \\
\hline
\end{tabular}

Table A2. Company characteristics.

\begin{tabular}{|c|c|}
\hline Variables and questions & Item measures \\
\hline \multicolumn{2}{|l|}{ General company characteristics } \\
\hline Number of employees (A1) & Single choice: $50-100,100-300$, over 300 \\
\hline Annual turnover (A2) & Single choice: below $100,100-500$, over 500 MSEK \\
\hline $\begin{array}{l}\text { What percentage of you total turnover is represented by } \\
\text { this customer (A3) }\end{array}$ & Single choice: $1-5,6-10,11-25,26-50$, over $50 \%$ \\
\hline $\begin{array}{l}\text { What is the physical distance between your company } \\
\text { and this customer (A4) }\end{array}$ & Single choice: below 10, 10-100, over $100 \mathrm{~km}$ \\
\hline The main customer is a (A5) & Single choice: retailer or other producing company \\
\hline $\begin{array}{l}\text { Where in the supply chain is your company situated } \\
\text { regarding the products delivered to your main } \\
\text { customer (A6) }\end{array}$ & $\begin{array}{l}\text { Multiple choice: OEM, delivering to the OEM, two } \\
\text { steps from the OEM, three or more steps from the } \\
\text { OEM }\end{array}$ \\
\hline The products delivered to your main customer are (A7) & $\begin{array}{l}\text { Single choice: specific for this customer, delivered } \\
\text { to several customers }\end{array}$ \\
\hline \multicolumn{2}{|l|}{ Information management practice ${ }^{\dagger}$} \\
\hline \multicolumn{2}{|l|}{ E1. Managing the information process } \\
\hline \multicolumn{2}{|c|}{ a - We use information mapping to improve our information management. } \\
\hline \multicolumn{2}{|c|}{$\mathrm{b}$ - We do regular reviews of what the information requirements are in the internal processes. } \\
\hline \multicolumn{2}{|c|}{$\mathrm{c}-$ We do regular reviews of what the information requirements are at the suppliers. } \\
\hline \multicolumn{2}{|c|}{$\begin{array}{l}\text { d-We confront information producers with information-quality deficiencies to get to the root of the problem. } \\
\text { E2. Managing the information life cycle }\end{array}$} \\
\hline \multicolumn{2}{|l|}{ a - We clean out old data from our information systems. } \\
\hline \multicolumn{2}{|l|}{ b - We clean our information systems from duplicates. } \\
\hline \multicolumn{2}{|l|}{ b - We regularly update our ERP data. } \\
\hline \multicolumn{2}{|l|}{ E3. Information official } \\
\hline $\begin{array}{l}\text { a - We have one or several employees responsible for } \\
\text { information quality. }\end{array}$ & Yes/No \\
\hline $\begin{array}{l}\mathrm{b} \text { - We have one or several employees responsible for } \\
\text { information management. }\end{array}$ & Yes/No \\
\hline \multicolumn{2}{|l|}{ E4. Supporting the planning process } \\
\hline \multicolumn{2}{|l|}{$\begin{array}{l}\text { a - We use the ERP system for order and forecast } \\
\text { management. }\end{array}$} \\
\hline $\mathrm{b}-$ We use an advanced planning system for forecastin & \\
\hline
\end{tabular}

Note: 'information-quality management level. Seven-point scales anchored by 'we do not use this at all' and 'this is a frequently used routine or practice for us' except for E3. 
Table A3. Respondents' company and customer characteristics.

\begin{tabular}{lc}
\hline Variable & $\begin{array}{c}\text { No. of respondents } \\
(\% \text { of all 219) }\end{array}$ \\
\hline Fewer than 100 employees & $120(55 \%)$ \\
Turnover larger than €50M & $60(27 \%)$ \\
Main customer stands for $>25 \%$ of turnover & $45(21 \%)$ \\
Distance to main customer $>100 \mathrm{~km}$ & $86(39 \%)$ \\
Respondent is an OEM, not a supplier & $50(23 \%)$ \\
Items delivered to the main customer are & $58(26 \%)$ \\
$\quad$ customer-specific & \\
\hline
\end{tabular}

Table A4. Industries and sizes of selection and respondents.

\begin{tabular}{lcccc}
\hline & $\begin{array}{c}\text { Selection } \\
(\text { No. })\end{array}$ & $\begin{array}{c}\text { Selection } \\
(\%)\end{array}$ & $\begin{array}{c}\text { Responses } \\
(\text { No. })\end{array}$ & $\begin{array}{c}\text { Responses } \\
(\%)\end{array}$ \\
\hline $\begin{array}{l}\text { Industry } \\
\begin{array}{l}\text { Mechanical engineering, and } \\
\quad \text { textile industries }\end{array}\end{array}$ & 696 & $77 \%$ & 148 & $68 \%$ \\
$\begin{array}{l}\text { Process type industries (food, } \\
\quad \text { chemistry, paper, etc.) }\end{array}$ & 209 & $23 \%$ & 71 & $32 \%$ \\
$\begin{array}{l}\text { Size (turnover) } \\
<€ 10 \mathrm{M}\end{array}$ & 196 & $22 \%$ & 42 & $19 \%$ \\
$€ 10-50 \mathrm{M}$ & 394 & $44 \%$ & 117 & $53 \%$ \\
$>€ 50$ & 315 & $35 \%$ & 60 & $27 \%$ \\
\hline
\end{tabular}

